\title{
Occupational infection and needle stick injury among clinical laboratory workers in Al-Madinah city, Saudi Arabia
}

\author{
Omar F. Khabour ${ }^{1,2^{*}}$ D, Khalil H. Al Ali ${ }^{1}$ and Waleed H. Mahallawi ${ }^{1}$
}

\begin{abstract}
Background: Clinical laboratory workers face biohazard such as needlestick injury and occupational infection on a daily basis. In this study, we examined self-reported frequency of occupational infection and needlestick injury among the clinical laboratory workers in Al- Madinah, Saudi Arabia.

Methods: A total of 234 clinical laboratory workers were recruited from private and government health sectors to answer a self-administered questionnaire that was prepared to achieve the aims of the study.

Results: The results showed that approximately $33 \%$ of the sample had an experienced occupational infection while 24\% had experienced a needlestick injury. Approximately, 49\% reported that they always recap needle after use, whereas $15 \%$ reported doing that most of the times. Occupational infection, needlestick injury and recapping needles after use were associated with lack of training on biosafety $(P<0.05)$.

Conclusion: The frequency of occupational infection and needlestick injury among clinical laboratory workers in Al-Madinah is high. Interventions related to biosafety and infection control and the use of needlestick prevention devices might be useful in lowering such frequency.
\end{abstract}

Keywords: Biosafety, Clinical laboratory, Al-Madinah, Occupational infection, Needlestick

\section{Background}

Clinical laboratory workers are subjected daily to occupational hazards that include infections from biological samples and contaminated equipment [1]. For example, literature showed that workers at clinical laboratory are at increased risk of acquiring viral infections such as hepatitis viruses (HBV and HCV), human immunodeficiency viruses (HIV), Middle East Respiratory Syndrome (MERS-CoV), and others [2, 3]. In addition, bacterial occupational infection has been shown to be high among clinical laboratory workers and other health care providers [4-6]. For example, in a study that was conducted in the United Kingdom, clinical laboratory workers were at about seven times higher risk of acquiring tuberculosis infection in reference to the general population [7].

\footnotetext{
* Correspondence: ofkhabour@taibahu.edu.sa

${ }^{1}$ Department of Clinical Laboratory Sciences, Taibah University, Al-Madinah 41477, Saudi Arabia

${ }^{2}$ Department of Medical Laboratory Sciences, Jordan University of Science and Technology, Irbid, Jordan

One of the major sources of infection among health care professionals is needlestick injuries [8,9]. According to the literature, needlestick injury is responsible for the majority of hepatitis and HIV infections among health care professionals. In addition, the majority of these infections occur in developing countries [10]. Analysis of needlestick injuries showed that injuries could happen during all steps of needle use procedures [8]. However recapping of the needle, work load and lack of training, and not following safety precautions are among major risk factors [11-13]. Requiring workers to follow procedures and practices related to infection control, injury prevention and the use of protective equipment can significantly reduce infections and needlestick injury $[14,15]$.

The aim of the current study is to investigate self-reported frequency of occupational infection and needlestick injury among the clinical laboratory workers in Al- Madinah. In addition, factors that are associated with these incidences were also examined. 
AL-Madinah city, the second holiest site in Islam after Mecca, receives more than 10 million pilgrims each year, who come from all the world. The city provides health services to pilgrims and residents through 10 major hospitals and several medical centers. The considerable diversity of patients and heavy load highlight the importance of adopting good practices and safety protection measures to limit the spread of diseases in the city. Therefore, this study was designed to examine the self-reported occurrence of needlestick injuries, safety practices (i.e. recapping), and occupational infection among laboratory workers in Al-Madinah. The results of the current study can be used for interventions that target the enhancement of biosafety measures among Al-Madinah clinical laboratory workers.

\section{Methods}

\section{Study participants}

A survey-based study design was adapted to investigate the incidence and factors associated with needlestick injury and occupational infection among clinical laboratory workers in Al-Madinah city. Al-Madinah is the second holy city after Mecca in Saudi Arabia that host the Prophet's Mosque. According to the Statistics Directorate, the population of Al-Madinah is estimated to be close to 1.5 million. The city receives more than 10 million pilgrims each year who came from most world countries.

Clinical laboratory staff from the majority of Al-Madinah clinics (eight private and ten governmental) was invited to be part of the study. Details about the purpose of the study and assurance of confidentiality were presented to participants as part of the recruitment procedure. About 405 participants were invited to fill out the questionnaire among which 234 agreed to participate (58\%). The questionnaire was anonymous and self-administered and required about 5-8 min to fill out. This anonymity was a requirement that ensured no possible risks for the participants. To ensure confidentiality, the research team has removed the IP addresses from the data spreadsheet after completion of the recruitment process. The study was approved by the Institutional Review Board of the Faculty of Applied Medical Sciences (ID number: MLT 2016-23).

\section{Study instrument}

The questionnaire was prepared from previous studies that examined needlestick injury, occupation safety and factors associated with their incidence [16-18]. The questionnaire comprised of 20 items that were presented with a choice of answers. The instrument was subjected to several revisions after comments were received from colleagues at the Department of Medical Laboratory Sciences and a pilot study that involved 20 staff from diagnostic clinical labs. The questionnaire was divided into three parts. The first part gathered information about participants' age, gender, experience, prior training on biosafety, specialty, academic degree and place of work. The second part focused on needlestick injury and related behaviors such as covering needle after use (re-sheathing or re-capping). In this part, the participants were asked if they have experienced a needlestick injury during their career period. In addition, the participant was asked about frequency of re-capping needles after use. The third part focused on occupational infection and knowledge about disinfection procedures and infection routes. Participants were asked if they have

Table 1 General characteristics of participants

\begin{tabular}{|c|c|c|c|}
\hline Variable & Category & $\begin{array}{l}\text { Number of } \\
\text { subjects }\end{array}$ & Percentage \\
\hline \multirow[t]{3}{*}{ Age } & $18-30$ & 135 & $57.7 \%$ \\
\hline & $31-40$ & 70 & $29.9 \%$ \\
\hline & $>40$ & 29 & $12.4 \%$ \\
\hline \multirow[t]{2}{*}{ Gender } & Male & 147 & $62.8 \%$ \\
\hline & Female & 87 & $37.2 \%$ \\
\hline \multirow[t]{3}{*}{ Social position } & Married & 130 & $55.6 \%$ \\
\hline & Single & 96 & $41.0 \%$ \\
\hline & Divorced/widowed & 8 & $3.4 \%$ \\
\hline \multirow[t]{2}{*}{ Place of work } & Governmental clinics & 132 & $56.4 \%$ \\
\hline & Private clinics & 102 & $43.6 \%$ \\
\hline \multirow[t]{3}{*}{ Academic degree } & College degrez & 30 & $12.8 \%$ \\
\hline & Bachelor degree & 167 & $71.4 \%$ \\
\hline & Graduate degree & 37 & $15.8 \%$ \\
\hline \multirow[t]{4}{*}{ Academic Field } & Laboratory Sciences & 174 & $74.4 \%$ \\
\hline & Applied Biology & 25 & $10.7 \%$ \\
\hline & Health Science & 19 & $8.1 \%$ \\
\hline & Others & 16 & $6.8 \%$ \\
\hline \multirow[t]{4}{*}{ Assigned work } & Clinical chemistry & 71 & $30.3 \%$ \\
\hline & Hematology & 99 & $42.3 \%$ \\
\hline & Histology/pathology & 27 & $11.5 \%$ \\
\hline & $\begin{array}{l}\text { Microbiology/ } \\
\text { Immunology }\end{array}$ & 37 & $15.8 \%$ \\
\hline \multirow[t]{4}{*}{ Years of experience } & $\leq 3$ & 91 & $38.9 \%$ \\
\hline & $4-6$ & 64 & $27.4 \%$ \\
\hline & $7-10$ & 50 & $21.4 \%$ \\
\hline & $>10$ & 28 & $12.0 \%$ \\
\hline \multirow[t]{4}{*}{ Position } & Residency & 50 & $21.4 \%$ \\
\hline & Technician & 141 & $60.3 \%$ \\
\hline & Lab director & 18 & $7.7 \%$ \\
\hline & Consultant & 25 & $10.7 \%$ \\
\hline \multirow[t]{2}{*}{ Training on Biosafety } & Yes & 152 & $65.0 \%$ \\
\hline & No & 82 & $35.0 \%$ \\
\hline
\end{tabular}


experienced an occupational infection, which was defined as acquiring bacterial or viral infection from work place during their career period. Participants filled the questionnaire electronically using google forms.

\section{Statistical analysis}

The SPSS software was used to analyze the data, which was presented as frequencies and number of participants in each category. Chi square test, Fisher Exact test and odd ratios with $95 \%$ confidence intervals were used to correlate demographic variables with needlestick and occupational infection. The $P$ value of significance was set at 0.05 threshold.

\section{Results}

A total of 234 medical laboratory workers was recruited to participate in the study. The majority (Table 1) of participants were young $(57.7 \%$, age range: $18-30)$, males $(62.8 \%)$, married (55.6\%), belong to governmental clinics (56.4\%), bachelor degree holder (71.4\%), have a specialty in clinical laboratory sciences $(74.4 \%)$, works as technicians $(60.3 \%)$ and received training on laboratory safety (65\%). About $40 \%$ have less than 3 years of experience, whereas $27.4 \%$ have between 4 and 6 years of experience (Table 1). The sample is well distributed according different branches of laboratory sciences that include clinical chemistry (30.3\%), hematology (42.3\%), histology (11.5\%) and microbiology/immunology (15.8\%). All

Table 2 Incidence of needle stick injuries among participants

\begin{tabular}{|c|c|c|c|c|c|c|}
\hline Variable & Category & $\begin{array}{l}\text { (Yes) Had needle } \\
\text { stick injuries }\end{array}$ & $\begin{array}{l}\text { (NO) Had needle } \\
\text { stick injuries }\end{array}$ & Odd ratio & $\begin{array}{l}95 \% \text { confidence } \\
\text { interval }\end{array}$ & $P$. value \\
\hline \multirow[t]{3}{*}{ Age } & $18-30$ & $32(57.2 \%)$ & $103(57.9 \%)$ & - & - & \\
\hline & $31-40$ & $18(32.1 \%)$ & $52(29.2 \%)$ & 1.123 & $0.60-2.09$ & 0.714 \\
\hline & $>40$ & $6(10.7 \%)$ & $23(12.9 \%)$ & 0.864 & $0.35-2.08$ & 0.739 \\
\hline \multirow[t]{2}{*}{ Gender } & Male & $39(69.6 \%)$ & $108(60.7 \%)$ & - & - & \\
\hline & Female & 17 (30.4\%) & $70(39.3 \%)$ & 0.672 & $0.37-1.20$ & 0.181 \\
\hline \multirow[t]{3}{*}{ Social status } & Married & $34(60.7 \%)$ & 96 (53.9\%) & - & - & \\
\hline & Single & $18(32.1 \%)$ & $78(43.8 \%)$ & 0.643 & $0.36-1.15$ & 0.139 \\
\hline & Divorced/widowed & $4(7.1 \%)$ & $4(2.2 \%)$ & 3.098 & $0.62-15.5$ & 0.167 \\
\hline \multirow[t]{2}{*}{ Place of work } & Governmental clinics & $25(44.6 \%)$ & 107 (60.1\%) & - & - & \\
\hline & Private clinics & 31 (55.4\%) & 71 (39.9\%) & 1.833 & $1.04-3.21$ & 0.034 \\
\hline \multirow[t]{3}{*}{ Academic degree } & College degree & $8(14.3 \%)$ & $22(12.4 \%)$ & - & - & \\
\hline & Bachelor degree & $38(67.9 \%)$ & $129(72.5 \%)$ & 0.798 & $0.34-1.84$ & 0.598 \\
\hline & Graduate degree & $10(17.9 \%)$ & $27(15.2 \%)$ & 1.020 & $0.36-2.88$ & 0.957 \\
\hline \multirow[t]{4}{*}{ Academic Field } & Laboratory Sciences & $40(71.4 \%)$ & $134(75.3 \%)$ & - & - & \\
\hline & Applied Biology & $9(16.1 \%)$ & $16(9.0 \%)$ & 1.877 & $0.77-4.52$ & 0.159 \\
\hline & Health Science & $6(10.7 \%)$ & $13(7.3 \%)$ & 1.452 & $0.55-3.81$ & 0.449 \\
\hline & Others & $1(1.8 \%)$ & $15(8.4 \%)$ & 0.261 & $0.05-1.28$ & 0.099 \\
\hline \multirow[t]{4}{*}{ Assigned work } & Clinical chemistry & $15(26.8 \%)$ & $55(30.9 \%)$ & - & - & \\
\hline & Hematology & $22(39.3 \%)$ & 77 (43.3\%) & 1.041 & $0.53-2.04$ & 0.906 \\
\hline & Histology/pathology & $8(14.3 \%)$ & 19 (10.7\%) & 1.460 & $0.56-3.75$ & 0.431 \\
\hline & Microbiology/Immunology & $10(17.9 \%)$ & $27(15.2 \%)$ & 1.377 & $0.58-3.24$ & 0.464 \\
\hline \multirow[t]{4}{*}{ Years of experience } & $\leq 3$ & $16(28.6 \%)$ & $75(42.1 \%)$ & - & - & \\
\hline & $4-6$ & $18(32.1 \%)$ & $46(25.8 \%)$ & 1.782 & $0.88-3.59$ & 0.106 \\
\hline & $7-10$ & $17(30.4 \%)$ & $33(18.5 \%)$ & 2.286 & $0.92-4.81$ & 0.062 \\
\hline & $>10$ & $4(7.1 \%)$ & $24(13.5 \%)$ & 0.724 & $0.26-2.01$ & 0.536 \\
\hline \multirow[t]{4}{*}{ Position } & Residency & $14(25.0 \%)$ & $36(20.2 \%)$ & - & - & \\
\hline & Technician & $32(57.1 \%)$ & 109 (61.2\%) & 0.747 & $0.37-1.49$ & 0.408 \\
\hline & Lab director & $7(12.5 \%)$ & $(6.2 \%) 11$ & 1.733 & $0.56-5.37$ & 0.341 \\
\hline & Consultant & $3(5.4 \%)$ & $22(12.4 \%)$ & 0.333 & $0.10-1.10$ & 0.072 \\
\hline \multirow[t]{2}{*}{ Training on Biosafety } & Yes & $29(51.8 \%)$ & $123(69.1 \%)$ & - & - & \\
\hline & No & $(48.2 \%) 27$ & (30.9\%) 55 & 2.054 & $1.15-3.66$ & 0.014 \\
\hline
\end{tabular}


participants were vaccinated against $\mathrm{HBV}$ as this a requirement by health law in Saudi Arabia before employment in medical laboratories.

The results showed that about $24 \%$ of the sample had experienced a needlestick injury. The results showed that the needlestick injury was associated with private clinics $(P<0.05)$ and lack of training on biosafety (Table 2). The participants were asked about capping needle directly after use. Approximately, 49\% reported that they always do that, whereas $15 \%$ reported doing that most of the times (Table 3). Recapping needle after use, was associated with governmental clinics $(P<0.01)$, technician/residency staff $(P<0.01)$ and lack of training $(P<0.05$, Table 3$)$. Table 4 shows the incidence of occupational infection among participants. The incidence was about $33 \%$ and it was associated with college degrees $(P<0.05)$ and training on biosafety $(P<0.05$, Table 4).

Figure 1 shows the awareness of participants about disinfection procedures and infection routes. The results showed that the majority of participants reported excellent to very good awareness levels (> 80\%).

\section{Discussions}

In this study, the incidence of occupational infection and needlestick injury among clinical laboratory workers in $\mathrm{Al}$-Madinah city was investigated.

Table 3 Covering needle directly after use as reported by participants expressed as number of participants (\%)

\begin{tabular}{|c|c|c|c|c|c|c|c|}
\hline Variable & Category & Always & Most Times & Neutral & Sometimes & Never & $P$. value \\
\hline \multirow[t]{3}{*}{ Age } & $18-30$ & $76(61.3)$ & $21(61.8)$ & $26(48.1)$ & $6(50.0)$ & $6(60.0)$ & 0.770 \\
\hline & $31-40$ & $35(28.2)$ & $8(23.5)$ & $18(33.3)$ & $6(50.0)$ & $3(30.0)$ & \\
\hline & $>40$ & $13(10.6)$ & $5(14.7)$ & $9(16.7)$ & $0(0.0)$ & $1(10.0)$ & \\
\hline \multirow[t]{2}{*}{ Gender } & Male & $80(64.55)$ & $18(52.9)$ & $36(66.7)$ & $8(66.7)$ & $5(50.0)$ & 0.610 \\
\hline & Female & $44(35.5)$ & $16(47.1)$ & $18(33.3)$ & $4(33.3)$ & $5(50.0)$ & \\
\hline \multirow[t]{3}{*}{ Social status } & Married & $73(58.9)$ & $18(52.9)$ & $27(50.0)$ & $7(58.3)$ & $5(50.0)$ & 0.804 \\
\hline & Single & $46(37.1)$ & $16(47.1)$ & $24(44.4)$ & $5(41.7)$ & $5(50.0)$ & \\
\hline & Divorced/widowed & $5(4.0)$ & $0(0.0)$ & $3(5.6)$ & $0(0.0)$ & $0(0.0)$ & \\
\hline \multirow[t]{2}{*}{ Place of work } & Governmental clinics & 79 (63.7) & $18(52.9)$ & $21(38.9)$ & $5(41.7)$ & $9(90.0)$ & 0.004 \\
\hline & Private clinics & $45(36.3)$ & $16(47.1)$ & $33(61.1)$ & $7(58.3)$ & $1(10.0)$ & \\
\hline \multirow[t]{3}{*}{ Academic degree } & College degree & $16(12.9)$ & $7(20.6)$ & $4(7.4)$ & $3(25.0)$ & $0(0.0)$ & 0.066 \\
\hline & Bachelor degree & $88(71.0)$ & $26(76.5)$ & $41(75.9)$ & $6(50.0)$ & $6(60.0)$ & \\
\hline & Graduate degree & $20(16.1)$ & $1(2.9)$ & $9(16.7)$ & $3(25.8)$ & $4(40.0)$ & \\
\hline \multirow[t]{4}{*}{ Academic Field } & Laboratory Sciences & $87(70.2)$ & $24(70.6)$ & $46(85.2)$ & $10(83.3)$ & $7(70.0)$ & 0.631 \\
\hline & Applied Biology & $14(11.3)$ & $4(11.8)$ & $4(7.4)$ & $1(8.3)$ & $2(20.0)$ & \\
\hline & Health Science & $10(8.1)$ & $4(11.8)$ & $3(5.6)$ & $1(8.3)$ & $1(10.0)$ & \\
\hline & Others & $13(10.5)$ & $2(5.9)$ & $1(1.9)$ & $0(0.0)$ & $0(0.0)$ & \\
\hline \multirow[t]{4}{*}{ Assigned work } & Clinical chemistry & $37(29.8)$ & $9(26.5)$ & $15(27.8)$ & $7(58.3)$ & $3(30.0)$ & 0.658 \\
\hline & Hematology & $50(40.3)$ & $17(50.0)$ & $25(46.3)$ & $3(25.0)$ & $4(40.0)$ & \\
\hline & Histology/pathology & $14(11.3)$ & $6(17.6)$ & $4(7.4)$ & $2(16.7)$ & $1(10.0)$ & \\
\hline & Microbiology/ Immunology & $23(18.5)$ & $2(5.9)$ & $10(18.5)$ & $0(0.0)$ & $2(20.0)$ & \\
\hline \multirow[t]{4}{*}{ Years of experience } & $\leq 3$ & $54(43.5)$ & $17(50.0)$ & $12(22.2)$ & $4(33.3)$ & $4(40.0)$ & 0.365 \\
\hline & $4-6$ & $31(25.0)$ & $6(17.6)$ & $18(33.3)$ & $5(41.7)$ & $4(40.0)$ & \\
\hline & $7-10$ & $23(18.5)$ & $8(23.5)$ & $16(29.6)$ & $3(25.0)$ & $0(0.0)$ & \\
\hline & $>10$ & $15(12.1)$ & $3(8.8)$ & $8(14.8)$ & $0(0.0)$ & $2(20.0)$ & \\
\hline \multirow[t]{4}{*}{ Position } & Residency & $32(25.8)$ & $8(23.5)$ & $10(18.5)$ & $0(0.0)$ & $0(0.0)$ & 0.001 \\
\hline & Technician & $74(59.7)$ & $19(55.9)$ & $37(68.5)$ & $6(50.0)$ & $5(50.0)$ & \\
\hline & Lab director & $9(7.3)$ & $4(11.8)$ & $3(5.6)$ & $0(0.0)$ & $2(20.0)$ & \\
\hline & Consultant & $9(7.3)$ & $3(8.8)$ & $4(7.4)$ & $6(50.0)$ & $3(30.0)$ & \\
\hline \multirow[t]{2}{*}{ Training on biosafety } & Yes & $69(55.6)$ & $24(70.6)$ & $46(85.2)$ & $7(58.3)$ & $6(60.0)$ & 0.024 \\
\hline & No & $55(44.4)$ & $10(29.4)$ & $8(14.8)$ & $5(41.7)$ & $4(40.0)$ & \\
\hline
\end{tabular}


Table 4 Incidence of occupational infection among participants

\begin{tabular}{|c|c|c|c|c|c|c|}
\hline Variable & Category & Yes & No & Odd ratio & 95\% confidence interval & $P$. value \\
\hline \multirow[t]{3}{*}{ Age } & $18-30$ & $47(60.2 \%)$ & $88(56.4 \%)$ & - & - & \\
\hline & $31-40$ & $23(29.5 \%)$ & 47 (30.1\%) & 0.933 & $0.50-1.74$ & 0.828 \\
\hline & $>40$ & $8(10.3 \%)$ & $21(13.5 \%)$ & 0.666 & $0.27-1.62$ & \\
\hline \multirow[t]{2}{*}{ Gender } & Male & $47(60.2 \%)$ & $100(64.1 \%)$ & - & - & \\
\hline & Female & 31 (39.7\%) & $56(35.9 \%)$ & 1.185 & $0.66-2.09$ & 0.560 \\
\hline \multirow[t]{3}{*}{ Social status } & Married & $43(55.1 \%)$ & 87 (55.8\%) & - & - & \\
\hline & Single & $29(37.2 \%)$ & 67 (42.9\%) & 0.876 & $0.49-1.55$ & 0.652 \\
\hline & Divorced/widowed & $6(7.7 \%)$ & $2(1.3 \%)$ & 7.12 & $0.84-59.86$ & 0.070 \\
\hline \multirow[t]{2}{*}{ Place of work } & Governmental clinics & $43(55.1 \%)$ & $89(57.1 \%)$ & - & - & \\
\hline & Private clinics & 35 (44.9\%) & $67(42.9 \%)$ & 1.084 & $0.620-1.895$ & 0.775 \\
\hline \multirow[t]{3}{*}{ Academic degree } & College degree & $17(21.8 \%)$ & $13(8.3 \%)$ & - & - & \\
\hline & Bachelor degree & $50(64.1 \%)$ & 117 (75.0\%) & 0.310 & $0.12-0.74$ & 0.009 \\
\hline & Graduate degree & $11(14.1 \%)$ & $26(16.7 \%)$ & 0.318 & $0.10-0.93$ & 0.037 \\
\hline \multirow[t]{4}{*}{ Academic Field } & Laboratory Sciences & $56(71.8 \%)$ & $118(75.6 \%)$ & - & - & \\
\hline & Applied Biology & $12(15.4 \%)$ & $13(8.3 \%)$ & 1.97 & $0.79-4.94$ & 0.144 \\
\hline & Health Science & $4(5.1 \%)$ & $15(9.6 \%)$ & 0.527 & $0.17-1.61$ & 0.264 \\
\hline & Others & $6(7.7 \%)$ & $10(6.4 \%)$ & 1.206 & $0.41-3.49$ & 0.729 \\
\hline \multirow[t]{4}{*}{ Assigned work } & Clinical chemistry & $29(37.2 \%)$ & $42(26.9 \%)$ & - & - & \\
\hline & Hematology & $28(35.9 \%)$ & $71(45.5 \%)$ & 0.571 & $0.29-1.10$ & 0.096 \\
\hline & Histology/pathology & $8(10.3 \%)$ & $19(12.2 \%)$ & 0.608 & $0.22-1.61$ & 0.317 \\
\hline & Microbiology/ Immunology & $13(16.7 \%)$ & $24(15.4 \%)$ & 0.827 & $0.35-1.94$ & 0.662 \\
\hline \multirow[t]{4}{*}{ Years of experience } & $\leq 3$ & $33(42.3 \%)$ & $58(37.2 \%)$ & - & - & \\
\hline & $4-6$ & $18(23.1 \%)$ & $46(29.5 \%)$ & 0.675 & $0.33-1.36$ & 0.272 \\
\hline & $7-10$ & $15(19.2 \%)$ & $35(22.4 \%)$ & 0.760 & $0.35-1.62$ & 0.478 \\
\hline & $>10$ & $11(14.1 \%)$ & $17(10.9 \%)$ & 1.23 & $0.48-3.10$ & 0.656 \\
\hline \multirow[t]{4}{*}{ Position } & Residency & 19 (24.4\%) & $31(19.9 \%)$ & - & - & \\
\hline & Technician & $47(60.3 \%)$ & $94(60.3 \%)$ & 1.400 & $0.57-3.39$ & 0.457 \\
\hline & Lab director & $5(6.4 \%)$ & $13(8.3 \%)$ & 0.750 & $0.24-2.29$ & 0.613 \\
\hline & Consultant & $7(9.0 \%)$ & $18(11.5 \%)$ & 0.751 & $0.29-1.91$ & 0.546 \\
\hline \multirow[t]{2}{*}{ Training on Biosafety } & Yes & $42(53.8 \%)$ & $110(70.5 \%)$ & - & - & \\
\hline & No & 36 (46.2\%) & 46 (29.5\%) & 2.085 & $1.16-3.74$ & 0.013 \\
\hline
\end{tabular}

With respect to the self-reported frequency of needlestick injury, approximately $24 \%$ of the sample had such experience during their career period. This rate is comparable to what was reported in some previous studies [16-18]. For example, an incidence rate of $22.4 \%$ sharp injuries over a period of 12 months was reported in a cross-sectional study that was conducted in Dominican Republic [16]. In an Egyptian cross-sectional interview-based study, about 36\% of participants reported exposure to at least 1 needlestick injury during the past 3 months [18]. However, higher frequencies (63-73\%) were reported in cross-sectional survey-based studies that were conducted in Bosnia [19] and Afghanistan [20] and include the whole career period.
Needlestick injuries reported in this study could be due to what was reported by the participants that they always (49\%) recap needle after use, whereas 15\% reported doing that most of the times. Recapping needle after use was associated technician/residency staff and lack of training. In a Poland study, $64 \%$ of respondents occasionally recap needles after injections [21]. In Morocco, 51\% reported recapping needles after use [22]. In a review that was conducted by De Carli and colleagues [8], issues related to management of sharp disposals, needle recapping, and the transfer of sampled blood from syringes into tubes account for the majority of needlestick injuries. Thus, behavior of medical staff plays an important in sharp injuries [23]. Needlestick and sharp injuries can be prevented by 


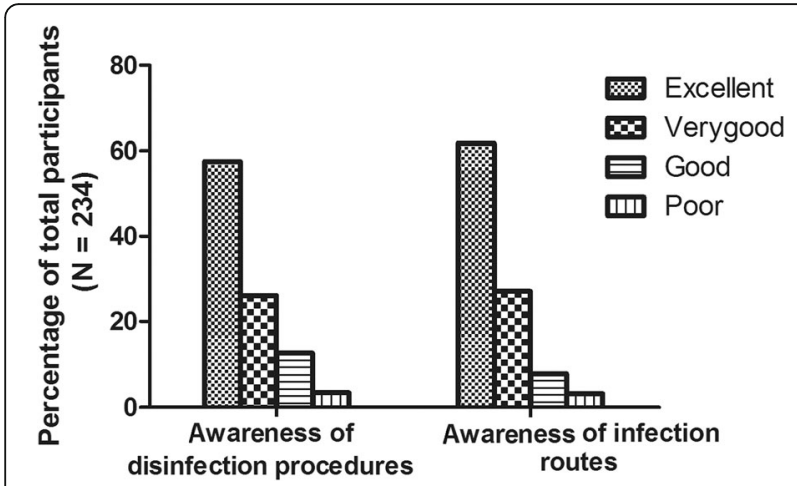

Fig. 1 Awareness of participants about disinfection procedures and infection routes. A total of 234 participants were included in the study. More than $80 \%$ of study sample reported having excellent to very good awareness about disinfection procedures and infection routes

applying educational and biosafety training programs and needle protective devices $[24,25]$. The finding of the present study that needlestick injuries were strongly associated with the lack of training on biosafety and private clinics confirmed the importance of education in reducing sharp injuries in medical laboratories. Finally, the results showed that needledstick injuries were less frequent in governmental clinics and recapping was performed more frequently. Thus, additional factors seem to contribute to needlestick injury, such as workloads and adherence to safety guidelines that are expected to differ in governmental and private clinics. More studies are required to determine the exact factors that contribute to the observed high frequency of needlestick injury among Al-Madinah clinical laboratory workers.

The results showed that approximately $33 \%$ of participants experienced occupational infection during their career period. Previous studies have shown increased risk of clinical laboratory workers to diverse types of infection from their work places [26] that include blood borne pathogens (HBV, HCV, HIV), respiratory illnesses (MERS-CoV, influenza viruses, Tuberculosis) [27] and skin infections [28]. In a cross-sectional survey study that was conducted in clinics from 10 Moroccan cities, $58.9 \%$ of the subjects underwent at least one occupational blood exposure [22]. The results showed an association between occupational infection and college degree holders and training on biosafety.

The results showed that $>80 \%$ of the sample reported very-good to excellent knowledge regarding infection routes and disinfection procedures. Thus, other factors apart from education are likely to play a role in determining incorrect behaviors such as the adherence to infection control guidelines. However, the association between needlestick injury and occupational infection with lack of training on biosafety highlights the importance of training in reducing such biohazards. Previous studies have pointed to the effectiveness of the adherence to infection control guidelines, use of injury prevention devices and biosafety educational programs in the prevention of occupational infection and injury $[29,30]$.

In this cross-sectional study, we asked the participants if they have ever experienced needlestick injury or occupational infection. To have a better assessment of the current situation, conduction of a longitudinal study is strongly recommended where the incidence of such biohazards can be accurately measured. Inclusion of more questions in the assessment such as how often the participants perform phlebotomy and whether they use needlestick prevention devices are strongly recommended. Other limitations include the validity of key measures such as recall bias and social desirability related to recapping practices, selection bias and the data were not adjusted for confounder factors.

In conclusion, the frequency occupational infection and needlestick injury among clinical laboratory workers in Al-Madinah was relatively high as self-reported by participants. Strict implementation of biohazard guidelines in the health care settings and the use of needlestick prevention devices are recommended to reduce the risk of occupational health infections.

\section{Acknowledgments}

Authors would like to thank the Clinical Laboratory Sciences Department at Taibah University for their support.

\section{Funding}

Taibah University.

\section{Availability of data and materials}

The datasets and all materials used during the current study available from the corresponding author on reasonable request.

\section{Authors' contributions}

All authors (OK, KA and WM) contributed to study design, data collection and data analysis/interpretations. OK prepared the first draft of the manuscript and Dr. KA and WM revised the first draft of the manuscript and finalized it. All authors read and approved the final manuscript.

\section{Ethics approval and consent to participate}

All participants gave informed consent according to the Research Ethics Committee of the Faculty of Applied Medical Sciences at Taibah University (approval number MLT201623).

\section{Competing interests}

The authors declare that they have no competing interests.

\section{Publisher's Note}

Springer Nature remains neutral with regard to jurisdictional claims in published maps and institutional affiliations.

Received: 12 February 2018 Accepted: 13 May 2018

Published online: 21 May 2018

\section{References}

1. Nathavitharana RR, Bond P, Dramowski A, et al. Agents of change: the role of healthcare workers in the prevention of nosocomial and occupational tuberculosis. Presse Med. 2017;46:e53-62. 
2. Pedrosa PB, Cardoso TA. Viral infections in workers in hospital and research laboratory settings: a comparative review of infection modes and respective biosafety aspects. Int J Infect Dis. 2011;15:e366-76.

3. Tarantola A, Abiteboul D, Rachline A. Infection risks following accidental exposure to blood or body fluids in health care workers: a review of pathogens transmitted in published cases. Am J Infect Control. 2006;34:367-75.

4. Auta A, Adewuyi EO, Tor-Anyiin A, et al. Health-care workers' occupational exposures to body fluids in 21 countries in Africa: systematic review and meta-analysis. Bull World Health Organ. 2017;95:831-41F.

5. Baron EJ, Miller JM. Bacterial and fungal infections among diagnostic laboratory workers: evaluating the risks. Diagn Microbiol Infect Dis. 2008;60:241-6.

6. Joshi R, Reingold AL, Menzies D, Pai M. Tuberculosis among health-care workers in low- and middle-income countries: a systematic review. PLoS Med. 2006:3:e494.

7. Tormey WP, O'Hagan C. Cerebrospinal fluid protein and glucose examinations and tuberculosis:will laboratory safety regulations force a change of practice? Biochem Med (Zagreb). 2015;25:359-62.

8. De Carli G, Abiteboul D, Puro V. The importance of implementing safe sharps practices in the laboratory setting in Europe. Biochem Med (Zagreb). 2014;24:45-56.

9. Marini MA, Giangregorio M, Kraskinski JC. Complying with the occupational safety and health Administration's Bloodborne pathogens standard: implementing needleless systems and intravenous safety devices. Pediatr Emerg Care. 2004;20:209-14.

10. Sabermoghaddam M, Sarbaz M, Lashkardoost $H$, et al. Incidence of occupational exposure to blood and body fluids and measures taken by health care workers before and after exposure in regional hospitals of a developing country: a multicenter study. Am J Infect Control. 2015; 43:1137-8.

11. Gabriel J. Reducing needlestick and sharps injuries among healthcare workers. Nurs Stand. 2009;23:41-4.

12. Matsubara C, Sakisaka K, Sychareun V, Phensavanh A, Ali M. Prevalence and risk factors of needle stick and sharp injury among tertiary hospital workers, Vientiane, Lao PDR. J Occup Health. 2017:59:581-5.

13. Motaarefi H, Mahmoudi H, Mohammadi E, Hasanpour-Dehkordi A. Factors associated with Needlestick injuries in health care occupations: a systematic review. J Clin Diagn Res. 2016;10:IE01-4.

14. Glenngard AH, Persson U. Costs associated with sharps injuries in the Swedish health care setting and potential cost savings from needle-stick prevention devices with needle and syringe. Scand J Infect Dis. 2009;41: 296-302.

15. Tarigan LH, Cifuentes M, Quinn M, Kriebel D. Prevention of needle-stick injuries in healthcare facilities: a meta-analysis. Infect Control Hosp Epidemiol. 2015;36:823-9.

16. Moro PL, Moore A, Balcacer P, et al. Epidemiology of needlesticks and other sharps injuries and injection safety practices in the Dominican Republic. Am J Infect Control. 2007;35:552-9.

17. Qazi AR, Siddiqui FA, Faridi S, et al. Comparison of awareness about precautions for needle stick injuries: a survey among health care workers at a tertiary care center in Pakistan. Patient Saf Surg. 2016;10:19.

18. Talaat M, Kandeel A, El-Shoubary W, et al. Occupational exposure to needlestick injuries and hepatitis B vaccination coverage among health care workers in Egypt. Am J Infect Control. 2003;31:469-74.

19. Musa S, Peek-Asa C, Young T, Jovanovic N. Needle stick injuries, sharp injuries and other occupational exposures to blood and body fluids among health care workers in a general hospital in Sarajevo, Bosnia and Herzegovina. Int J Occup Saf Health. 2014;4:31-7.

20. Salehi AS, Garner P. Occupational injury history and universal precautions awareness: a survey in Kabul hospital staff. BMC Infect Dis. 2010;10:19.

21. Rogowska-Szadkowska D, Stanislawowicz M, Chlabicz S. Risk of needle stick injuries in health care workers: bad habits (recapping needles) last long. Przegl Epidemiol. 2010;64:293-5.

22. Laraqui $\mathrm{O}$, Laraqui $\mathrm{S}$, Tripodi $\mathrm{D}$, et al. Assessing knowledge, attitude, and practice on occupational blood exposure in caregiving facilities, in Morocco. Med Mal Infect. 2008:38:658-66.

23. Castella A, Vallino A, Argentero PA, Zotti CM. Preventability of percutaneous injuries in healthcare workers: a year-long survey in Italy. J Hosp Infect. 2003; 55:290-4.

24. Adams D. Needlestick and sharps injuries: practice update. Nurs Stand. 2012; 26:49-57. quiz 58
25. Wilburn SQ. Needlestick and sharps injury prevention. Online J Issues Nurs. 2004;9:5.

26. Wei $Q$, Li XY, Wang $L$, et al. Preliminary studies on pathogenic microorganisms laboratory-acquired infections cases in recent years and its control strategies. Zhnghua Shi Yan He Lin Chuang Bing Du Xue Za Zhi. 2011;25:390-2

27. Chughtai AA, Seale H, Dung TC, et al. Compliance with the use of medical and cloth masks among healthcare Workers in Vietnam. Ann Occup Hyg. 2016;60:619-30.

28. Duman Y, Yakupogullari Y, Otlu B, Tekerekoglu MS. Laboratory-acquired skin infections in a clinical microbiologist: is wearing only gloves really safe? Am J Infect Control. 2016;44:935-7.

29. Rice BD, Tomkins SE, Ncube FM. Sharp truth: health care workers remain at risk of bloodborne infection. Occup Med (Lond). 2015;65:210-4.

30. Trim JC, Elliott TS. A review of sharps injuries and preventative strategies. J Hosp Infect. 2003;53:237-42.

\section{Ready to submit your research? Choose BMC and benefit from:}

- fast, convenient online submission

- thorough peer review by experienced researchers in your field

- rapid publication on acceptance

- support for research data, including large and complex data types

- gold Open Access which fosters wider collaboration and increased citations - maximum visibility for your research: over $100 \mathrm{M}$ website views per year

At BMC, research is always in progress.

Learn more biomedcentral.com/submissions 